\title{
PENERAPAN LEARNING CYCLE "5E" MELALUI MEDIA AUDIO- VISUAL UNTUK MENINGKATKAN KEMAMPUAN PEMAHAMAN KONSEP SISWA PADA PEMBELAJARAN IPS
}

\author{
Harmawati \\ PGSD FKIP UBP Karawang \\ e-mail: harmawatisps@yahoo.com
}

\begin{abstract}
This research was motivated by concern for the quality of learning conditions IPS diminishing due to the low aspect of the ability of understanding the concept of students, the learning process is still conventional and centered on the teacher. This study uses a class action carried out this study in three cycles each cycle consists of four stages, namely Planning (Planning), Action (Acting), Observation (Observation), and Reflection (Reflection). Based on the findings of research that has been conducted on the application of Learning Cycle "5E" through audio-visual media to increase understanding of the concept of students in learning social studies in elementary school, it can be concluded that the model Learning cycle with the help of audio-visual media in the learning process there was an increase teacher performance, help students to understand the concept of learning social studies so that students can maximize learning and reaches a value corresponding to the KKM. This is evidenced by the increasing number of tests at the end of each cycle
\end{abstract}

\section{Keywords: Learning Cycle "5E", Media Audio Visual, Concept}

\begin{abstract}
Abstrak: Penelitian ini dilatar belakangi oleh keprihatinan terhadap kondisi kualitas pembelajaran IPS yang semakin menurun disebabkan oleh rendahnya aspek kemampuan pemahaman konsep siswa, proses belajar masih bersifat konvensional dan berpusat pada guru. Penelitian ini menggunakan metode tindakan kelas Penelitian ini di laksanakan 3 siklus yang setiap siklusnya terdiri dari empat tahapan yaitu Perencanaan (Planning), Tindakan (Acting), Pengamatan (Observation), dan Refleksi (Reflection). Berdasarkan temuan hasil penelitian yang telah dilakukan mengenai penerapan Learning Cycle "5E" melalui media audio visual untuk meningkatkan pemahaman konsep siswa pada pembelajaran IPS di SD, maka dapat disimpulkan bahwa model Learning cycle dengan bantuan media audio visual dalam proses pembelajaran terjadi peningkatan kinerja guru, membantu siswa untuk memahami konsep pembelajaran IPS sehingga siswa dapat memaksimalkan pembelajaran dan mencapai nilai yang sesuai dengan KKM. Ini dibuktikan dengan meningkatnya jumlah tes akhir pada setiap siklusnya.
\end{abstract}

\section{Kata kunci : Learning Cycle "5E", Media AudioVisual,Pemahaman Konsep.}





\section{PENDAHULUAN}

IPS berasal dari literatur pendidikan Amerika Serikat. Nama asli IPS di Amerika Serikat adalah "Social Studies". Social Scence Education Council (SSEC) menyebut IPS sebagai "Social Science Education”, sedangkan National Council for Social Studies (NCSS), menyebut IPS dengan istilah "Social Studies". NCSS (1994: 3) telah mendefinisikan IPS sebagai berikut :

Social studies is the integrated study of the social sciences and humanities to promote civic competence. Within the school program, social studies provides coordinated, systematic study drawing upon such disciplines as anthropology, archeology, economics, geography, history, law, philosophy, political science, psychology, religion, and sociology, as well as appropriate content from the humanities, mathematics, and natural sciences. The primary purpose of social studies is to help young people develop the ability to make informed and reasoned decisions for the public good as citizens of a culturally diverse, democratic society in an interdependent world.

Pengertian tersebut di atas menunjukkan bahwa IPS merupakan kajian terintegrasi dari ilmu-ilmu sosial dan humaniora untuk mengembangkan nilai kewarganegaraan. Pendidikan mengandung arti bahwa siswa harus dipersiapkan untuk berpartisipasi secara efektif dalam dinamika kehidupan masyarakat. Siswa memiliki kesadaran untuk meningkatkan prestasinya sebagai bentuk tanggung jawab warganegara yang setia pada negara. Pendidikan nilai dalam tujuan ini lebih ditekankan pada kewarganegaraan. Materi yang disajikan, misalnya ketika berbicara tentang lingkungan sekolah, maka anak diminta untuk belajar dengan baik. Mereka adalah generasi penerus yang akan menggantikan generasi sekarang. Hal lain yang dapat disimpulkan dari pengertian dia atas adalah bahwa pendidikan IPS yang diberikan di persekolahan pada jenjang dasar sampai pendidikan menengah, ditandai dengan keterpaduan.

Mata pelajaran IPS dirancang untuk mengembangkan pengetahuan, pemahaman, dan kemampuan analisis terhadap kondisi sosial masyarakat dalam memasuki 
kehidupan bermasyarakat yang dinamis. Selain itu mata pelajaran IPS bertujuan agar siswa memiliki kemampuan dasar untuk berpikir logis dan kritis, rasa ingin tahu, inkuiri, memecahkan masalah, dan keterampilan dalam kehidupan sosial (Sapriya, 2009:194).

Dalam implementasinya di lapangan berbagai upaya untuk meningkatkan kualitas proses pembelajaran yang berlangsung dalam pembelajaran Ilmu pengetahuan sosial (IPS). IPS merupakan salah satu mata pelajaran yang diajarkan di SD dan juga merupakan salah satu disiplin ilmu yang di dalamnya mengkaji tentang peristiwa, fakta, konsep, dan generalisasi yang berkaitan dengan isu-isu sosial. Pembelajaran IPS ini diajarkan tidak secara terpisah, melainkan didasarkan pada pendekatan terpadu (integrated) yang mengacu pada aspek kehidupan nyata (factual) peserta didik sesuai dengan karakteristik usia, tingkat perkembangan berpikir, dan kebiasaan bersikap dan perilakunya.

Pembelajaran IPS memiliki tujuan yang harus dicapai oleh peserta didik sesuai dengan Permendiknas nomor 22 tahun 2006, yaitu: (1)mengenal konsep-konsep yang beruk berkaitan dengan kehidupan masyarakat dan lingkungannya,(2) memiliki kemampuan dasar untuk berpikir logis dan kritis, rasa ingin tahu, inkuiri, memecahkan masalah, dan keterampilan dalam kehidupan sosial, (3) memiliki komitmen dan kesadaran terhadap nilai-nilai sosial dan kemanusiaan, dan (4) memiliki kemampuan berkomunikasi, bekerjasama dan berkompetensi dalam masyarakat yang majemu, di tingkat lokal, nasional dan global.

Untuk mencapai tujuan-tujuan pembelajaran tersebut maka setiap peserta didik harus dibekali dengan berbagai kompetensi yang sesuai dengan tujuan pembelajaran IPS. Kompetensi peserta didik sebagai hasil pembelajaran di sekolah dapat menentukan tingkat kehidupan mereka menjalani kehidupan di masyarakat baik dalam lingkup lokal, nasional maupun global. Artinya kompetensi itu sangat penting bagi setiap orang dalam menghadapi perkembangan zaman yang begitu pesat, terlebih dalam menghadapi era 
globalisasi yang ditandai dengan bebasnya arus informasi yang diterima, gaya hidup yang yang konsumtif bahkan memungkinkan lunturnya norma suatu bangsa. Sehingga dengan dimilikinya kompetensi, siswa dapat mengantisipasi perkembangan zaman dan mampu berperan aktif di dalamnnya serta diharapkan mampu memecahkan permasalahan kehidupan yang dihadapi dengan cara lebih baik, lebih cepat, adaptif, dan solutif.

Pada saat ini proses pembelajaran IPS yang dilaksanakan hampir sebagian besar sekolah selalu dihadapkan pada proses pembelajaran yang masih konvensional yaitu pembelajaran yang lebih banyak aktif adalah gurunya dengan metode ceramah yang menjadi metode favorit pada setiap pembelajaran. Siswa didominasi untuk lebih banyak mengikuti kemauan guru, sedangkan siswa tidak diberi kesempatan untuk menemukan sendiri suatu konsep yang dipelajarinya. Padahal IPS merupakan mata pelajaran yang materinya lebih banyak konsepkonsepyang bersifat abstrak. Konsep- konsep abstrak ini harus dapat dipahami oleh siswa. Kemudian setelah dipahami siswa mampu menerapkan dalam kehidupan kesehariannya. Sehingga siswa setelah mempelajari IPS dapat merasakan manfaat dan dampaknya dalam kehidupan sehari-hari.

Pada umumnya guru-guru melaksanakan pembelajaran IPS lebih banyak -memberikan konsep-konsep yang hanya berupa hafalan tanpa tahu arti dan makna konsep yang dipelajarinya. Guru selalu memberikan definisi dari suatu konsep atau istilah tanpa mengetahui proses dari kegiatan yang membentuk konsep tersebut. Siswa pun menerima penjelasan dari guru apa adanya tanpa ada bantahan meski dalam hati maupun proses berpikirnya bertanya. Hal ini dengan asumsi bahwa siswa belum memiliki pengetahuan apa-apa dari rumahnya. Siswa hanya menjadi pendengar dan mencatat dengan baik dari materi yang disampaikan guru. Dengan demikian kompetensi yang dimiliki oleh siswa menjadi tidak berkembang optimal.

Konsep-konsep IPS ini harus dimaknai dengan pengertian yang 
jelas dan mampu dipahami oleh siswa. Apalagi konsep dalam IPS lebih banyak konsep yang bersifat abstrak, artinya konsep tersebut tidak dapat dilihat dan diamati secara langsung. Hal yang diamati hanya dari efek tingkah laku individunya. Dengan demikian perlu adanya proses penjelasan tentang penguasaan konsep yang jelas, kemudian siswa mampu menerapkan konsep tersebut dalam kehidupan sehari-harinya.

Sejalan dengan pendapat Nasution (Istianti, 2007, hlm. 2) bahwa Pengajaran IPS menuntut penguasaan atas konsep-konsep dasar dari berbagai cabang ilmu sosial dan fakta-fakta dari masyarakat serta lingkungan sekitarnya. Proses belajar yang tidak mengaitkan bahan yang diajarkan dengan pengalaman belajar yang tidak dimiliki, akan tidak bermakna atau tidak memberi arti bagi perkembangan diri siswa .

Berdasarkan hasil pengamatan terhadap proses pembelajaran IPS di beberapa SD ditemukan bahwa pembelajaran masih bersifat konvensional, Sehingga dalam proses pembelajarannya sedikit terabaikan dan hanya memberikan materi yang bersifat hafalan. Hal ini juga jauh dari karakteristik IPS yang merupakan mata pelajaran untuk mengembangkan pemahaman konsep sebagai bekal untuk siswa dalam menjalani kehidupan baik di lingkungan sekolah, rumah dan lingkungan masyarakatnnya.

Dalam pembelajaran yang dilaksanakan guru SD pada mata pelajaran IPS selama ini banyak yang menggunakan pendekatan pembelajaran yang lebih banyak berpusat pada guru (teacher centered) diarahkan pada pendekatan pembelajaran yang berpusat pada siswa (student centered). Sebagai konsekuensi dari pendekatan yang berpusat pada siswa ini menuntut adanya peran guru sebagai penyedia layanan (fasilitator), memotivasi siswa untuk mau belajar motivator, dan membimbing siswa untu mencapai kompetensi yang diharapkan.

Peneliti menetapkan alternative tindakan untuk meningkatkan pemahaman konsep belajar siswa dengan menerapkan model Learning Cycl e " $5 E$ " melalui bantuan media audiovisual. Model Pembelajaran 
learning cycle atau biasa disebut LC adalah suatu model pembelajaran yang berpusat pada siswa (student centrated) yang dikembangkan pertama kali oleh Science Curriculum Improvement Study (SCIS) pada tahun 1970-1974.

Model pembelajaran ini dilandasi oleh pandangan kontruktivisme. Piaget beranggapan bahwa dalam belajar pengetahuan itu itu dibangun sendiri oleh anak dalam belajar kognitif melalui interaksi dengan lingkungannya. Pada awalnya learning cycle hanya mempunyai tiga fase yaitu eskplorasi (exploration), pengenalan konsep (concept introduction) dan aplikasi konsep (concept aplication). Ketiga tahap tersebut kemudian disempurnakan oleh Lorsbach (dalam Wena, 2011) menjadi 5 tahap yaitu: pembangkitan minat (engagemet), eksplorasi (eksploration), penjelasan (explanation), elaborasi (elaboration), evaluasi (evaluation).

Media berasal dari bahasa latin yaitu medius yang secara harfiah berarti tengah, perantara, atau pengantar. Dalam bahasa Arab, kata media disebut wasaala bentuk jamak dari wasilah (Sukiman, 2012, hlm. 28). Jadi secara bahasa media berarti pengantar pesan dari pengirim kepada penerima pesan. Melalui penggunaan media komunikasi seperti media audio visual yang tidak hanya dapat mempermudah dan mengefektifkan proses pembelajaran, akan tetapi juga dapat membuat proses pembelajaran lebih menarik (Sanjaya, 2010, hlm. 162)

Kamus Bahasa Indonesia menjelaskan bahwa pemahaman berasal dari kata "paham" yang artinya "mengerti benar" (Surayin, 2003, hlm. 396). Pemahaman merupakan terjemahan dari kata understanding yang maksudnya adalah sebagai penyerapan arti dari suatu materi pelajaran yang sedang dipelajari . sedangkan konsep berarti suatu rancangan.

Bloom (Sudjana, 2005, hlm. 45) menyatakan bahwa pemahaman adalah kemampuan menangkap materi yang disajikan dalam bentuk yang dapat dimengerti dan mampu memberikan interpretasi serta mampu mengklarifikasikannya sehingga diperlukan hubungan konsep dan makna dari konsep tersebut. 
Pemahaman tersebut diperoleh dari proses pembelajaran yang dirasakan dan dialami seseorang dan memiliki indicator individu terdapat menjelaskan informasi yang dimilikinya melalui bahasa sendiri.

Berdasarkan uraian latar belakang tersebut maka peneliti mengkaji penelitian tindakan kelas dengan judul "Penerapan Learning Cycle " $5 E$ " melalui Media Audio Visual untuk Meningkatkan Pemahaman Konsep Siswa pada Pembelajaran IPS pada Siswa kelas IVE SDN Nagasari VI Kabupaten Karawang.

\section{METODE PENELITIAN}

Penelitian ini termasuk penelitian tindakan kelas karena peneliti ingin memperbaiki proses pembelajaran dengan model pembelajaran Learning Cycle " $5 E$ " melalui media yang dapat meningkatkan kemampuan pemahaman konsep siswa. Tempat penelitian ini dilaksanakan di Sekolah Dasar Negeri Nagasari VI Kabupaten Karawang berlokasi di Jl. Husni Hamid No. 13 Kecamatan Karawang
Barat Kabupaten Karawang. Subyek penelitian adalah siswa kelas tinggi yaitu kelas IV E Sekolah Dasar Negeri Nagasari VI semester genap tahun pelajaran 2014/ 2015. jumlah siswa 44 orang, terdiri dari 25 siswa laki-laki dan 19 siswa perempuan. Pada penelitian tindakan kelas dilakukan dengan memberikan tindakan dengan model pembelajaran. Pada siswa diberi perlakuan khusus yaitu dalam proses pembelajaran dilakukan dengan menerapkan model Learning Cycle “ $5 E$ ”. Untuk variabel bebas yang lain yaitu media Audio Visual dalam pembelajaran IPS, variabel ini dijadikan sebagai variabel yang ikut mempengaruhi variabel terikat yaitu kemampuan pemahaman konsep siswa. Desaign yang digunakan dalam penelitian ini adalah model Kemmis dan Mc. Taggart dalam perencanaan Kemmis menggunakan system refleksi diri dimulai dari perencanaan, pelaksanaan, observasi, dan refleksi Penelitian ini menggunakan dua jenis instrument, yaitu instrument tes dan non tes. Instrument tes terdiri dari seperangkat soal untuk mengukur pemahaman konsep siswa pada 
pembelajaran IPS. Uraian mengenai instrument penelitian yang berupa: test (pretest dan posttest) kemampuan pemahaman konsep siswa akan diuji coba (Analisis, reabilitas, daya pembeda, dan tingkat kesukaran instrument) dan berbentuk uraian. Sedangkan instrument non tes adalah lembar observasi. Penelitian ini Instrumen yang digunakan dalam penelitian ini adalah lembar observasi. Pedoman observasi ini digunakan untuk mengetahui peningkatan siswa dari mulai pretest sampai kepada posttest.

Penelitian ini dapat dikatakan berhasil apabila pada akhir siklus Kriteria Ketuntasan belajar pemahaman konsep siswa pada mata pelajaran IPS kelas IV yaitu 73 dari setiap siswa. Pelaksanaan tindakan siklus I dilaksanakan pada tanggal 29 April 2015 pada pukul 09.2511.15 WIB di SDN Nagasari VI Kabupaten Karawang. Siklus I dilaksanakan dengan alokasi waktu 3 jam pelajaran. Pembelajaran pada pertemuan ini diikuti 44 siswa, materi pada pertemuan ini adalah teknologi produksi tradisional dan modern. Pelaksanaan siklus 2 dilaksanakan pada hari Rabu tanggal 6 Mei 2015 pada pukul 07.15 -09.00 WIB dengan alokasi waktu yaitu 3 jam pelajaran (3 x 35 menit). Pelaksanaan pembelajaran siklus 2 dihadiri oleh 43 siswa dikarenakan 1 orang siswa sedang sakit. Dalam pembelajaran siklus 2 ini tidak jauh berbeda dengan siklus sebelumnya. Materi pada pertemuan ini adalah teknologi komunikasi masa lalu dan masa kini. Pelaksanaan siklus 3 dilaksanakan pada hari Rabu tanggal 12 Mei 2015 pada pukul 07.15 -09.00 WIB dengan alokasi waktu yaitu 3 jam pelajaran (3 x 35 menit). Pelaksanaan pembelajaran siklus 3 dihadiri oleh seluruh siswa yaitu 44 orang siswa. Dalam pembelajaran siklus 3 ini tidak jauh berbeda dengan siklus sebelumnya. Materi pada pertemuan ini adalah teknologi transportasi masa lalu dan masa kini.

Dari tabel terlampir dapat disimpulkan bahwa pemahaman konsep siswa pada kompetensi dasar mengenal perkembangan produksi, komunikasi, dan transportasi serta pengalaman menggunakannya 
mengalami peningkatan untuk setiap siklusnya. Hal ini terlihat jelas pada peningkatan nilai rata-rata kelas dan peningkatan presentase. Untuk memperjelas peningkatan angka ketuntasan belajar, di bawah ini disajikan dalam bentuk gambar berikut ini:

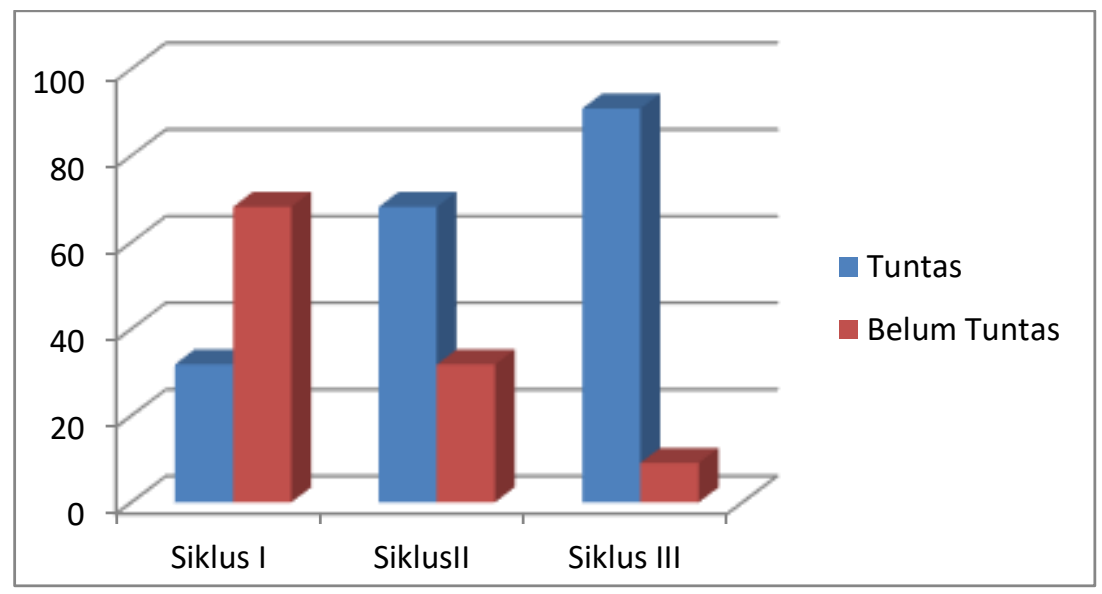

Gambar 1

Ketuntasan Belajar Siswa

Berdasarkan diagram di atas dapat disimpulkan bahwa ketuntasan belajar untuk setiap siklusnya mengalami peningkatan. Dari 44 orang siswa kelas IV SDN Nagasari VI, pada siklus I siswa dinyatakan tuntas belajar mencapai $31.82 \%$ atau 14 orang siswa dan $68.18 \%$ atau 30 orang siswa yang belum tuntas belajar. Pada siklus II mengalami perbaikan dengan pencapaian $68.18 \%$ atau 30 orang siswa tuntas belajar dan $31.28 \%$ atau 14. Siklus III sebagai siklus terakhir menunjukkan data 90.91 atau 40 orang siswa tuntas belajar dan $9.09 \%$ siswa belum tuntas belajar. Oleh sebab itu pembelajaran terkait peningkatan kemampuan pemahaman konsep siswa dinyatakan berhasil karena mencapai lebih dari $80 \%$ sebagai keberhasilan yang telah ditentukan sebelumnya.

Rekapitulasi data hasil observasi kinerja guru pada siklus I, II dan III disajikan dalam tabel berikut: 
Tabel 1

Hasil Pengamatan Kinerja Guru Siklus I, II dan III

\begin{tabular}{|c|c|c|c|c|}
\hline No & Keterangan & Siklus 1 & Siklus 2 & Siklus 3 \\
\hline-1 & Total Skor & 34 & 43 & 50 \\
\hline 2 & Kategori & Baik & Baik & $\begin{array}{c}\text { Sangat } \\
\text { Baik }\end{array}$ \\
\hline 3 & Presentasi Kinerja Guru & $60,71 \%$ & $80,35 \%$ & $89,28 \%$ \\
\hline
\end{tabular}

Berdasarkan tabel hasil Total skor rata-rata siklus I adalah pengamatan kinerja guru pada siklus 34 , total skor rata-rata siklus II I, II dan siklus III diketahui adalah 43 sedangkan total skor siklus menunjukkan terjadi peningkatan. III adalah 50.

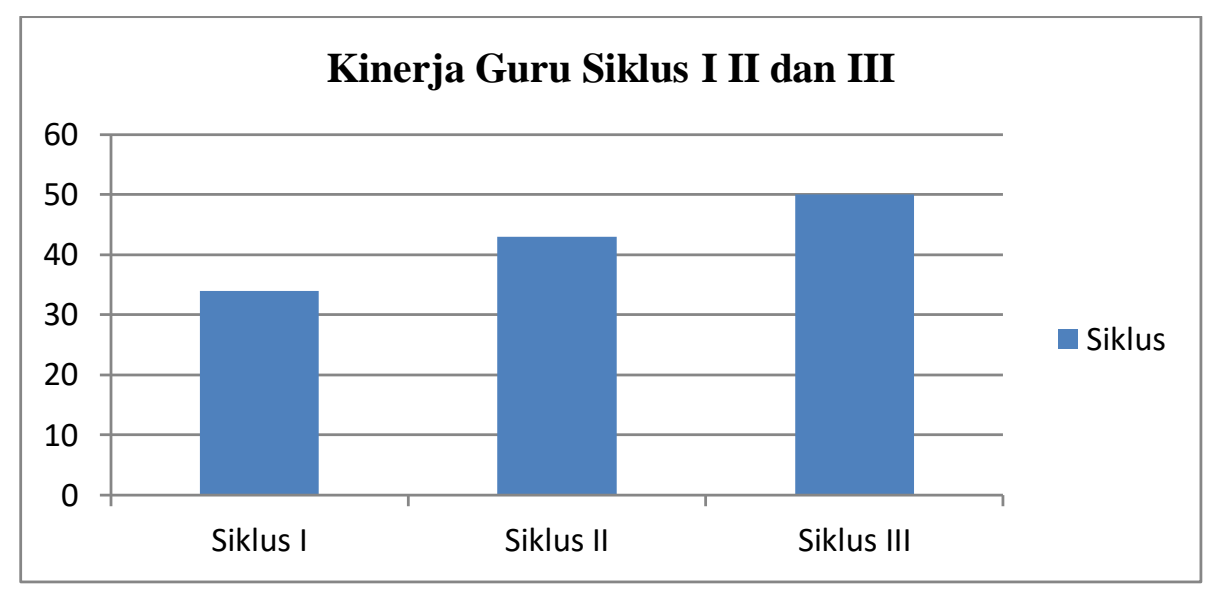

Gambar 2

Kinerja Guru Siklus I II dan III

Peningkatan kinerja guru juga disertai dengan peningkatan hasil pemahaman siswa dan hasil observasi aktivitas siswa. Berikut disajikan rekapitulasi data hasil pemahaman siswa pada siklus I, siklus II dan III.

\section{PENUTUP}

Berdasarkan hasil penelitian tindakan kelas peneliti menarik beberapa kesimpulan, berkaitan dengan penerapan Learning Cycle "5E" untuk meningkatkan kemampuan pemahaman konsep siswa melalui media audio-visual pada pembelajaran IPS di Kelas IV E SDN Nagasari VI Karawang terbukti berhasil bahwa:

1. Model Learning Cycle "5E" dapat meningkatkan kinerja 
guru, aktivitas siswa dan pemahaman konsep siswa melalui media audio visual pada siswa kelas IV SDN Nagasari VI Kabupaten Karawang.

2. Kinerja guru dalam setiap tindakan pembelajaran mengalami peningkatan, hal ini disebabkan adanya usaha guru untuk memanfaatkan hasil refleksi melakukan poin-poin penting yang yang menjadi kunci keberhasilan yaitu menggali kemampuan awal siswa dan menghubungkan dengan pemahaman konsep siswa, menunjukkan penggunaan media pembelajaran yaitu berupa media audio-visual yang mempermudah siswa menyerap materi pembelajaran, menyajikan materi pembelajaran secara runtut dan jelas sesuai dengan model pembelajaran Learning cycle "5E", menciptakan suasana belajar yang kondusif dan menyenangkan serta interaksi antara siswa dengan siswa, guru dengan siswa, siswa dengan media selama proses pembelajaran. Pada kinerja guru pada siklus I jumlah skor 34 jika dipresentasikan 60,71\% dengan kategori baik. Pada siklus II jumlah skor 43 kategori baik karena presentase kinerja guru mencapai $80,35 \%$, pada siklus III meningkat dilihat dari segi kategori menunjukkan sangat baik dengan presentase 89,28.

3. Hasil tes pemahaman konsep siswa pada materi perkembangan teknologi produksi, komunikasi dan transportasi menunjukkan adanya peningkatan pengetahuan siswa untuk setiap siklusnya. Hal ini ditandai dengan perolehan nilai rata-rata mencapai 67,1 dengan ketuntasan klasikal $31,82 \%$ pada siklus I, meningkat menjadi 78 , ketuntasan belajar $70,45 \%$ pada siklus II, meningkat menjadi 87,6 ketuntasan klasikal 90,91 pada siklus III. Oleh sebab itu maka tindakan pembelajaran 
dinyatakan berhasil arena mencapai $80 \%$ siswa yang tuntas belajar sebagai target yang sudah ditentukan sebelumnnya.

4. Hasil pengamatan aktifitas siswa mengalami peningkatan setiap siklusnya. Dari delapan indikator yang menjadi fokus pengamatan seluruh siswa jumlah skor yaitu 14, 6 bila dikategorikan yaitu dengan kategori cukup pada siklus I, pada siklus II meningkat mencapai skor 19,8 dengan kategori baik dan pada siklus terakhir yaitu siklus III mencapai skor 22,9 dengan kategori sangat baik. Pencapaian siklus III telah berhasil dengan demikian maka tindakan perbaikan aktifitas siswa dinyatakan berhasil.

\section{DAFTAR RUJUKAN}

Baharuddin dan Wahyuni, E. N. (2012). Teori Belajar dan Pembelajaran. Jogjakarta: ArRuzz Media.

Banks. (1977). Teaching strategis for the social studies Inquiri, valuing, and decision-making. seattle . university of washington: addison wesley publishing company .

Effendi, R. d. (2009). Pengembangan pendidikan IPS SD. Direktorat Jenderal Pendidikan Tinggi Departemen Pendidikan Nasional.

Gunawan, R. (2013). Pendidikan IPS filosofi, konsep dan aplikasi. Bandung: Alfabeta.

Halloway, J. E \& Chiod, J. J. (2009). Social Studies is Being Taught in the Elementary School: A Contrarian View. Copyright Journal of Social Studies Research

Hanuscin, D, L., and Lee M, H, (2008). Using the Learning Cycle as a Model for Teaching the Learning Cycle to Preservice Elementary Teachers. Journal of Elementary Science Education, Vol. 20, No. 2 (Spring 2008), pp. 51-66. C2008 Document and Publication Services, Western Illinois University.

Hardiyasa, I, M,. Suma, K,. Sadia I, W,. (2014). Pengaruh Model Siklus Belajar 5E Terhadap Keterampilan Berpikir Kreatif dan Motivasi Berprestasi Siswa.E-Journal Program Pascasarjana Universitas Pendidikan Ganesha Program Studi IPA. Vol 4. Tahun 2014.

Hermawan, R. (2007). Metode Penelitian Pendidikan Sekolah Dasar. Bandung: UPI Press. Indikka, K. (2012). Pengembangan green behavior pada siswa melalui penggunaan 
media audio visual dalam metode pembelajaran examples non examples pada mata pelajaran IPS . Bandung: Tidak dipublikasikan.

Indikka，K. (2014). Pengembangan Green Behavior pada Siswa Melalui Penggunaan Media Audio Visual dalam Metode Pembelajaran Axamples Non Examples pada Mata Pelajaran IPS di Sekolah Dasar. Bandung: UPI.

Istianti, T, dan Kartika, E (2007) Pengembangan Strategi Pengajaran Konsep dalam Pembelajaran Ilmu Pengetahuan Sosial di Sekolah Dasar: Jurnal Pendidikan Dasar Universitas Pendidikan Indonesia. Vol.V. No: 7 -April 2007.

Longworth, N. (1999). Making lifelong learning work : learning cities for a learning century. London: Kogan page limited.

Marek, E. A. (2008). Why the Learning Cycle?. Journal Journal of Elementary Science Education, Vol. 20, No. 3 (Summer 2008), pp. 63-69. (C)2008 Document and Publication Services, Western Illinois University.

Maxim, G. W. (2010). Dynamic Social Studies for Constructivist Classroom: Inspiring Tomorrow's Social Scientists (Ninth Editon)i. Boston: Allyn \& Bacon, Pearson.
National Counsil for Social Studies. (1994). Expectance of Excelence: Curriculum Standards for Social Studies. Washingt on D.C : NCSS.

Permendiknas RI No. 22 Tahun 2006 Standar Isi

Poerwanti, E. (2008). Assesmen Pembelajaran SD. Jakarta : Direktorat Jenderal Pendidikan Tinggi Departemen Pendidikan Nasional.

Radjiman \& Triyono A. (2009). Ilmu Pengetahuan Sosial:untuk Sekolah Dasar Kelas IV. Jakarta: Pusat Perbukuan Depdiknas.

Saptiarso, E. S. (2009). Ilmu Pengetahuan Sosial 4:untuk SD dan MI Kelas IV. Jakarta: Pusat Perbukuan Depdiknas.

Sagala, S. (2009). Konsep dan Makna Pembelajaran. Bandung : Alfabeta.

Samsiani. (2009). "Implementasi Pendekatan Open-Ended dalam Pembelajaran IPS untuk Meningkatkan Kemampuan Berpikir Kritis dan Hasil Belajar Siswa. Bandung: Tidak diterbitkan.

Sanjaya, W. (2010). Strategi Pembelajaran Berorientasi Standar Proses Pendidikan. Jakarta: Prenada Media Grup.

Santa. (2013). Santa, (2013). Penerapan Pendekatan Savi (Somatik,Audio,Visual, Dan Intelegensi)d alam Pembelajaran IPS Untuk Meningkatkan 
Ecolitecacy Siswa Kelas 4 SD. Universitas Pendidikan Indonesia. Bandung: Tidak Dipublikasikan.

Setiawan, K., Khair, A., Siswantoro (2013). Penggunaan Media Audio Visual ada Pembelajaran IPS Siswa Kelas IV SD. Jurnal Universitas Lampung.

Syaodih, N. \& Syaodih, E.(2012). Kurikulum dan Pembelajaran Kompetensi. Bandung Refika Aditama.

Santrock, J. W. (2007a). Psikologi Pendidikan. Jakarta: Kencana.

Santrock, J. W. (2012b). Life-Span Defelopment.Jakarta:Erlangga.

Sapriya. (2009). Pendidikan IPS Konsep dan Pembelajaran 2. Bandung: PT Remaja Rosdakarya.

Saputri, I. (2014). Pengaruh Model Learning Cycle terhadap Pemahaman Konsep dan Kemampuan Berpikir Kritis Siswa dalam Pembelajaran Ilmu Pengetahuan Sosial. Bandung: Tidak diterbitkan.

Skeel, D. (1995). Elementary social studies; chalanges for tomorrow's world . USA: Harcourt Brace \& Company.

Solihatin, E. R. (2007). Cooperative learning . Jakarta: Bumi Aksara.

Sudjana, N. (2005). Penilaian Hasil Poses Belajar Mengajar. Bandung: Rosdakarya.
Sukiman. (2012). Fungsi Media ( Pengembangan Media Pembelajaran). Sleman Yogakarta: Pustaka Intan Madani.

Supardan, D. (2014). Pendidikan Ilmu Pengetahuan Sosial: Perspektif Filosofi, Kurikulum dan Pembelajaran. Bandung.

Supardan, D. (2014). Pendidikan IPS, perspektiffilosofi, kurikulum dan pembelajaran. Bandung.

Surayin. (2003). Kamus Umum Bahasa Indonesia. Bandung: Yrama Widia.

Tantya,dkk. (2008) Ilmu Pengetahuan Sosial: untuk SD/MI Kelas 4.Jakarta: Pusat Perbukuan Depdiknas. 
